\title{
Governance Systems Analysis (GSA): A Framework for Reforming Governance Systems
}

\author{
Allan Dale (Corresponding author) \\ The Cairns Institute, James Cook University \\ PO Box 6811, Cairns QLD 4870, Australia \\ Tel: + 61740421894 E-mail: allan.dale@jcu.edu.au \\ Karen Vella and Ruth Potts \\ School of Environment, Griffith University \\ 170 Kessels Road, Nathan QLD 4111, Australia \\ Tel: +61 7555 27113E-mail: k.vella@griffith.edu.au
}

Received: July 17, 2013 Accepted: August 13, $2013 \quad$ DOI: 10.5296/jpag.v3i3.4385

\begin{abstract}
Most commentators understand that contemporary social, economic and environmental challenges require quality governance from global to local scales. While public scrutiny of governance has increased in recent years, the literature on frameworks and methods for analysis in complex, poly-centric and multi-thematic governance systems remains fragmented; displaying many disciplinary or sectoral biases. This paper establishes a stronger theory-based foundation for the analysis of complex governance systems. It also develops a clear analytical framework applicable across a vast array of differing governance themes, domains and scales (GSA). The key methodological steps and evaluative criteria for the GSA framework are determined and practical guidance for its application in reform is provided.
\end{abstract}

Keywords: Governance systems analysis, governance reform, poly-centricity. 


\section{Introduction}

If governance is viewed as the "intentional shaping of the flow of events so as to realize desired public good" (Parker \& Braitwaite, 2003, p.119), then governance theory over the last half century has shifted dramatically. In the past, many assumed governance to be a hierarchical concept, driven by some form of authoritative leadership; often presuming an inseparable link between the concepts of governance and the processes of government (Thomas \& Grindle, 1990). Now, governance is more often understood to represent a wider set of processes of bargaining and negotiation among differing interests in society, leading to particular system outcomes (Dorcey, 1986; Emerson et al., 2011).

Public and academic attention to governance will no doubt continue to increase as civil society across the globe experiences new challenges to our environmental sustainability, economic wellbeing and social stability(Grahamet al.,2003;Kempet al., 2005; Weiss, 2000). Many understand that the contemporary challenges facing the world will enhance scrutiny on the quality of governance at all scales; from global to local (Younget al., 2006).

Despite a shift in theory from linear to more systemic concepts, however, most governance analysis (including research, review and evaluation) is still framed in terms of formalized, linear evaluation models (e.g., Hoggarth \& Comfort, 2010; Rauschemayer et. al, 2009). The literature also tends to offer up fragments of understanding about governance activity within:

1. Isolated themes or domains of activity within a much wider (if not global) set of inter-connected governance arrangements;

2. Key institutions and organizations involved within this wider governance context (e.g., large corporations, particular government agencies, etc.); or

3. Particular functional aspects of governance within key institutions or themes (e.g., collaboration, information management, capacity and leadership, etc.).

Indeed, there is considerable inconsistency in the way the term governance is used in the literature (Stoker, 1998). It is often not well defined before its application in an analytical sense. Political scientists tend to refer to it as the act of policy-making in the public sector. Public administration and organizational theorists apply it in the corporate sense to refer to decision-making within institutions (public and private). Different disciplines, including economics, political science, sociology, psychology, law, anthropology, public administration and planning often tend to consider governance differently. Finally, an overwhelming feature of the literature is that scholarship often focuses on understanding specific dimensions of governance at particular spatial scales and around particular thematic issues.

In systemic terms, however, it needs to be understood that all governance activities (whether corporate, thematic or functionally-oriented) should be positioned within the globe's wider socio-ecological and governance systems (Giovanni \& Silver, 1999); including the overall mix of multiple players, methods of influence and types of decisions made by institutions and individuals across the private, community and government sectors. Thus, analyzing components of the globe's governance system in any thematic context (e.g., from the 
environment to the economy) or at any scale requires reference to the place such analyses hold within the wider global system (Reed \& Bruyneel, 2010).

The globe's wider governance system (and significant sub-systems within it) is poly-centric and multi-themed. Further, systems, by their very nature, are not orchestrated by any one player, and no one individual or institution is in charge per se. It is the impact of a vast array of interactions among many independent decisions that determine system outcomes (Kemp, et al., 2005; Lockwood et al.2010).

This paper develops a systems-oriented framework for the analysis of any component within the globe's overarching governance system. The approach enables analysts to more powerfully contextualize their work and rests on the premise that any attempt to improve key components within the globe's governance system, no matter how small, should also maximize their benefit to the wider system. This is needed as isolated forms of governance analysis and reform that are poorly integrated within the wider governance system can have limited benefit and can even be counter-productive. Consequently, undertaking governance analysis within a much clearer contextual framework might mean analytical effort is targeted more towards the greatest risks of failure within the wider governance system.

\section{Why a Systemic Approach to Governance Analysis?}

Much of the governance literature emerges from the policy analysis, environmental science and corporate governance literature. This brings a positivist conception to analysis of the way things get done in society. Increasingly, however, there is recognition that society functions as a complex system (Folkeet al., 2005), including all-pervasive feedback loops between the natural world and the social world of human beings. It is becoming increasingly difficult for system managers to address key societal problems without first contextualizing them within the wider socio-ecological systems in which they reside. Indeed, Paavola et al. state:

A key contributionof the political science literature to research on environmental governance is a distinction between 'governance frameworks', which include those specific, purposive governance interventions that are developed and delivered by multiple actors at multiple scales in pursuit of a broad goal (i.e. the protection of biodiversity), and broader 'governance regimes', which encompass the whole range of customs, norms, and rules that shape a particular object (e.g. the levels of biodiversity that are in fact realized) (Paavola et al., 2009, p.149).

Thus, Raushmayer et al.(2009) usefully consider that combining evaluations of governance process and outcomes can overcome challenges to evaluating governance. There are, however, few analytical frameworks or empirical evaluations which consider the impact of governance on outcomes in complex multi-level, multi-stakeholder and multi-issue systems (e.g. Kenwardet al. 2011, Newig \& Fritsch, 2009). Little has been done to develop standardized or rigorous ways for analyzing and improving governance in systemic terms.

This paper suggests that structural-functional schools of sociology provide an opposite conceptual framework for building theory that casts society as a complex system whose component parts work together to promote solidarity and stability (Macionis\& Gerber, 2011). 
Whilst structuralism deals with institutions and institutional alliances that carry our particular roles within the system, functionalism focuses on the overall ability of the system to work effectively (Urry, 2000). Functionalism is based on the notion that all of the elements that make up a society are inter-connected, and that the qualities of this connectivity influence system outcomes. Functional elements of governance give insight into how the system is working through and around the institutions (or alliances) that carry out particular systemic roles. Both concepts relate well to Paavola et al.'s (2009) understanding of governance frameworks (specific purposive arrangements at any scale) and governance regimes (formal and informal rules which interact to shape behavior). The application of sociological theory, however, enables deeper analysis than the environmental governance literature.

Since the general decline of structural-functional thinking in the social sciences (from around the 1960s), social theory has explored many complementary schools of thought that help us to better understand the outcomes emerging from the health, or otherwise, of our social system, and consequently our governance systems. Conflict theories, for example remind us that power imbalances within society (caused by several functional defects) can lead to the marginalization of key actors from decision making structures (e.g., those social structures involved in setting societal objectives). Further, the theory of structuration (Giddens, 1984)opens up the possibilities of more inclusive decision making. Indeed, some of these schools of sociological thought have focused on the role of structuralism within society (Dixon \& Rhys, 2003), while others (Emerson et al., 2011) have focused on functional aspects of society (e.g., key societal outcomes achieved via the health of decision making processes).

\section{Understanding Key Features of Governance Systems}

The world faces several major social, economic and environmental risks and opportunities. While we often think of the technical things that need to be done to address these, little attention is focused on the fact that governance reform mobilizes technical effort. There is a tendency to analyze the physical or economic sciences behind the problem rather that the more sociologically-based governance flaws that led to the problem in the first place. Internationally, and in many nation-states, major reforms can come and go with little or no analysis of the health of the governance system. Consequently, huge shifts in policies and programs can occur based on little or no analysis of the health of the governance system.

This approach cannot continue; an approach where governance analysis barely exists or is a normative afterthought once other (more technical) analyses are complete. Explicit analysis of governance systems, as a precursor for supporting transformational change or informed continuous improvement, is needed. The literature on systemic frameworks for governance analysis, however, is thin. This paper provides a robust analytical framework that can be applied across any governance context. First, however, it explores the key features of the globe's governance system and significant thematic governance sub-systems. For the remainder of this paper, these sub-systems are referred to as governance systems, with it being understood that they are only components of a wider global system.

The following defines four key common features that need to be explored to build a 
genuinely systemic and holistic understanding of governance systems.

\subsection{Thematic Aspects of Governance}

Governance systems concerning social, economic and environmental themes of our society at any scale cannot be viewed in isolation (Plummer \& Armitage, 2007). Poor economic well-being, for example, often underpins social dysfunction. Social and cultural factors drive natural resource degradation. Natural resource degradation is a well known pre-cursor to economic collapse (Diamond, 2006). Despite this, governance analysis and research frequently hones in separately on social, economic and environmental governance themes in isolation. Indeed, thinking within such themes is often held hostage to the most allied scientific disciplines. The economic sciences (that inform economic governance systems) are often poorly informed by the bio-physical sciences. Equally, the biophysical science thinking that dominates governance in environmental themes often marginalizes the utility of the social and economic sciences (Dale et al., 2002).

Within social, economic and environmental themes, major domains of governance can also be defined. In the social theme, for example, we may pay attention to major domains such as health, justice, social development, education, etc. Again, at the domain level, governance analysis and research frequently hones in on distinct domains in isolation from each other.

Finally, within governance domains, there may again be significant activity-based sub-domains of critical importance to the overall health of the system. Domains and sub-domains tend to represent distinct governance activities that draw in particular expertise sets and distinct stakeholder communities. Consequently, structures operating within particular domains and sub-domains have a tendency to build their own cultures and eventually to operate as silos of activities within the wider governance system. Within a major environmental domain such as coastal management, for example, there may be several major sub-domains, including regulation, statutory planning, land use planning, river improvement and farm management, etc. The regulatory sub-domain tends to attract professional cultures and stakeholders with a real interest in punitive compliance. Hence, once again, within the literature, at the sub-domain level, governance research and analysis frequently focuses on distinct sub-domains in isolation, even though the business of regulation cannot be adequately separated from land use planning or voluntary management actions.

They key implication here is that, in undertaking governance analysis, we must be painfully aware that different governance themes, domains and sub-domains are highly inter-connected, both between and within particular spatial and times scales.

\subsection{Polycentric Aspects of Governance}

Within any theme or domain of governance, different sub-domains tend to play out at different spatial scales, and these scales operate in a polycentric (not hierarchical) fashion (Ostrom, 2008). The importance of spatial scale and inter-dependencies between scales has been drawn out in the adaptive management literature since the mid-1980s (Bulkeley, 2005). 
Cash et al. (2007) usefully define the importance of multiple levels of governance across the spatial scale. Again using an example from the coastal management domain, Table 1 shows how one might contextualize governance analysis in a particular domain. This illustrates that governance systems at any particular spatial scale are influenced by, and in turn influence, governance and consequent system outcomes arising from different spatial scales. In contextualizing any governance analysis, key scales often include, international, national, provincial, regional, local, property, paddock and site/project scales.

Table 1. An example of how themes, domains and sub-domains relate at different scales.

\begin{tabular}{|c|c|c|c|c|c|}
\hline \multicolumn{2}{|c|}{ Environmental Theme } & \multicolumn{2}{|l|}{ Social Theme } & \multicolumn{2}{|c|}{ Economic Theme } \\
\hline $\begin{array}{l}\text { Coastal } \\
\text { ManagementDomain }\end{array}$ & $\begin{array}{l}\text { Biodiversity } \\
\text { Domain }\end{array}$ & $\begin{array}{l}\text { Primary } \\
\text { Resources } \\
\text { Domain }\end{array}$ & $\begin{array}{l}\text { Marine } \\
\text { ResourcesDomain }\end{array}$ & $\begin{array}{l}\text { Water } \\
\text { Resources } \\
\text { Domain }\end{array}$ & $\begin{array}{l}\text { Atmospheric } \\
\text { Resources } \\
\text { Domain }\end{array}$ \\
\hline \multicolumn{6}{|c|}{ International Coastal Management Sub-Domains } \\
\hline $\begin{array}{l}\text { Convention } \\
\text { Concerning the } \\
\text { Protection of the } \\
\text { World's Cultural and } \\
\text { Natural Heritage } \\
\text { System }\end{array}$ & $\begin{array}{l}\text { Global } \\
\text { Program of } \\
\text { Action for } \\
\text { the } \\
\text { Protection of } \\
\text { the Marine } \\
\text { Environment } \\
\text { from } \\
\text { Land-based } \\
\text { Activities } \\
\text { System }\end{array}$ & $\begin{array}{l}\text { International } \\
\text { Convention } \\
\text { on Climate } \\
\text { Change } \\
\text { System }\end{array}$ & $\begin{array}{l}\text { UN Convention } \\
\text { on the Law of the } \\
\text { Sea System }\end{array}$ & $\begin{array}{l}\text { Convention } \\
\text { for the } \\
\text { Protection of } \\
\text { the Natural } \\
\text { Resources } \\
\text { and } \\
\text { Environment } \\
\text { of the South } \\
\text { Pacific } \\
\text { Region } \\
\text { System }\end{array}$ & $\begin{array}{l}\text { Agenda } \\
\text { 21-Chapter } \\
\text { 17: Rio } \\
\text { Declaration } \\
\text { on } \\
\text { Environment } \\
\text { and } \\
\text { Development } \\
\text { System }\end{array}$ \\
\hline \multicolumn{6}{|c|}{ National Coastal Management Sub-Domains (Australian) } \\
\hline \multicolumn{2}{|c|}{$\begin{array}{l}\text { Great Barrier Reef Marine Park } \\
\text { System }\end{array}$} & \multicolumn{2}{|c|}{$\begin{array}{l}\text { National Sea Change Taskforce } \\
\text { System }\end{array}$} & \multicolumn{2}{|c|}{$\begin{array}{l}\text { Environment Protection and } \\
\text { Biodiversity Conservation } \\
\text { System }\end{array}$} \\
\hline \multicolumn{6}{|c|}{ Provincial/ State Coastal Management Sub-Domains (State of Queensland) } \\
\hline $\begin{array}{l}\text { Coastal } \\
\text { Management System }\end{array}$ & $\begin{array}{l}\text { Major Project } \\
\text { Assessment } \\
\text { System }\end{array}$ & $\begin{array}{l}\text { Queensland } \\
\text { Property } \\
\text { Planning } \\
\text { System }\end{array}$ & $\begin{array}{l}\text { Reef Protection } \\
\text { System }\end{array}$ & $\begin{array}{l}\text { Sustainable } \\
\text { Planning } \\
\text { System }\end{array}$ & $\begin{array}{l}\text { River } \\
\text { Improvement } \\
\text { System }\end{array}$ \\
\hline \multicolumn{6}{|c|}{ Regional Coastal Management Sub-Domains (Wet Tropics Region) } \\
\hline $\begin{array}{l}\text { Regional Coastal } \\
\text { Planning System }\end{array}$ & $\begin{array}{l}\text { Regional } \\
\text { Land Use } \\
\text { Planning } \\
\text { System }\end{array}$ & $\begin{array}{l}\text { Coastal } \\
\text { Works } \\
\text { Management } \\
\text { System }\end{array}$ & $\begin{array}{l}\text { River } \\
\text { Improvement } \\
\text { Planning and } \\
\text { Delivery System }\end{array}$ & $\begin{array}{l}\text { Regional } \\
\text { Farm } \\
\text { Planning and } \\
\text { Management } \\
\text { System }\end{array}$ & $\begin{array}{l}\text { Coastal } \\
\text { Reserves } \\
\text { Management } \\
\text { System }\end{array}$ \\
\hline \multicolumn{6}{|c|}{ Local Coastal Management Sub-Domains (Wet Tropics Region) } \\
\hline $\begin{array}{l}\text { Traditional Owner } \\
\text { Country-Based }\end{array}$ & $\begin{array}{l}\text { Local } \\
\text { Planning }\end{array}$ & $\begin{array}{l}\text { Coastal } \\
\text { Works }\end{array}$ & $\begin{array}{l}\text { Local Catchment } \\
\text { and River }\end{array}$ & $\begin{array}{l}\text { Property } \\
\text { Plans and }\end{array}$ & $\begin{array}{l}\text { Coastal } \\
\text { Reserve }\end{array}$ \\
\hline
\end{tabular}


Planning System

Schemes and Development Approval System

\subsection{Structural Aspects of Governance}

The concept of structure offers an account of a system's key components: a configuration of purpose-oriented activities or a collection of inter-related services (Pullan \& Bhadeshia, 2000) that comprise the overall system. Well defined structural components with a particular role within the system, however, may indeed be represented as a network featuring many-to-many links between structures; outcomes from one structural component continually feeding into and informing outcomes from the others.

Often, the social sciences refer to structures within society as being the institutions (e.g., governments, corporations, families, etc.) or alliances of institutions with particular systemic roles. There are, for example, structures involved in setting visions or goals for society for particular themes, domains or sub-domains. While traditional governance thinking would tend to stress the structural importance of government agencies versus local government, industry, the not-for-profit sector and other civil institutions, governance systems are better understood by accepting that many different institutions are often involved in collectively carrying out these structured roles within society.

This is why, to facilitate the analysis of governance systems, we refer to structural aspects of governance as those key arch-typical activities within the decision making cycle that are generally deemed to be universally important. As a basis for analysis, consistent consideration of these important structural components of governance is critical as adaptive (or even linear) decision making is incomplete without the holistic inclusion of structured activities typically referred to within standard policy, planning or action learning cycles.

Drawing on the policy, planning and management literature (e.g., Althaus et. al.,2007), the following describes the standard structural activity components of governance systems that could be reliably applied to any theme, domain and sub-domain:

- Vision and objective setting: Setting higher level visions/objectives;

- Analysis: Research and assessment to underpin decision-making;

- Strategy development: Determining the best strategies for securing visions and strategic objectives, inclusive of an appropriate solutions mix (i.e., balancing market, suasive, regulatory, collaborative and capacity building approaches);

- Implementation: Implementation and delivery of broader strategies; and

- Monitoring, evaluation and review: Monitoring, evaluating and reviewing and implementation against the original vision and objectives.

Linear analysis of institutions operating within governance systems constrains thinking about possible new alliance-based pathways for decision making. Visionary decision-making, for 
example, doesn't necessarily need to be done only by government agencies, but could indeed be conducted by a genuine alliance of government, industry, community and not-for profit institutions. Equally, monitoring and evaluation is not necessarily the sole domain for research institutions, but could be achieved through collaborative ventures among different types of institutions. This should encourage analysts not to be too deterministic about who should be doing what in any given part of the globe's governance system, so long as the basic structural components of good decision-making are functioning.

\subsection{Functional Components of Governance}

Apart from ensuring the key structural elements of our governance systems are in place (i.e., the things that need to be done), it is equally important to consider how well things are working within and across these structural elements. Great integration of effort in vision/objective setting structures, for example, can be undone by poor integration of effort within and across strategy development and implementation structures. This provides a focus for analyzing how the system works (i.e., its functionality), against all the key structural elements of the system. Dale and Bellamy (1998) suggest there are three cornerstone functional elements of healthy governance systems.

\subsubsection{Knowledge Application to Improve Governance Systems}

Improving the functionality of any governance system requires integrated use of knowledge derived from multiple epistemologies (Leys \& Vanclay, 2011). This improves the understanding that key participants involved in decision-making have of their part of the globe's governance system. The creative use of appropriate knowledge delivery systems (e.g., through databases, mapping programs and decision support systems) is also crucial (Cundill \& Fabricius, 2009). In a technical sense, a wide understanding of biophysical, social, institutional and economic aspects of the system are required. Dale et al. (2002), for example, outline how the marginalization of the social sciences routinely undermines good-decision making in environment and natural resource themes and domains.

As knowledge improves within the system, this new knowledge also needs to be regularly linked to decision-making within the system's structural arrangements (Bouwen \& Taillieu, 2004). Related to this is the fact that durable approaches to knowledge management are also critical, avoiding inefficiencies inherent in a typical cycle of knowledge gathering followed by corporate knowledge loss. Traditional approaches to decision-making in various scales often involve 'one off' knowledge gathering activities carried out and controlled by individual agencies involved in various structural activities (Cundill \& Fabricius, 2009).

\subsubsection{Securing Connected Effort within Governance Systems}

Power relationships drive connections within and between structural components of any governance system. This is recognized in the socio-political analysis literature and in governance theory related to social development. Haider \& Rao (2010), for example, particularly analyze five separate analytical methods focused on understanding power relationships among key societal segments in international development. 
Many governance systems consist of isolated activities within and between different structural components of the system (Margerum, 1995). Several institutions in a particular nation, for example, may be actively setting national visions and targets for social development without ever connecting; at best duplicating effort and at worst working at cross-purposes. Great strategy development effort might equally have no link to structural monitoring activities, meaning success or failure can never actually be measured.

Securing effective connectivity within a system is difficult as many institutions, or sections within institutions, tend to operate as isolated silos (Morrison et al., 2004). This is understandable as they may be resource poor and power-hungry, leading them to isolate themselves rather than adopting the power-sharing arrangements required for genuine collaborative effort to work. The inefficiency costs of operating in isolation, however, can generally be greater than risks arising from effective power-sharing.

For collaborative and integrated effort to work, leadership is essential and investment is needed to drive system connectivity. Well designed arrangements that encourage fair bargaining and negotiation both within and between different institutions are required, but are rarely managed professionally. Many institutions operate on the assumption that the existing institutional arrangements within their own agency or unit are up to the job. Little effort often goes into building arrangements that encourage negotiation between stakeholders. This leads to ineffective governance and fails to either reach binding agreements between stakeholders or to manage conflict when policy or program proposals are presented and assessed.

While there is emerging focus on "collaborative" governance as a new concept (e.g., Emmerson et al., 2011; Hajer \& Wagenaar, 2003), we take the view that varying levels of collaboration have always been a part of the functionality of governance systems, and that separating out collaboration (a part of connectivity) as a new thing only serves to elevate its importance above other functional aspects (e.g., capacity or knowledge use). All governance systems have been or are collaborative to a greater or lesser extent, but there is a need to focus on optimizing the collaborative effort needed to make the system work effectively.

\subsubsection{Improving the Decision-Making Capacity of System Participants}

Anything that develops the decision-making capacity of institutions (e.g., agencies, communities, corporations, families, etc.) and individuals within a governance system will help improve the system's vitality (Dorcey, 1986). Attention to building the capacity of all system participants often needs to include:

- Building their understanding of and access to information concerning issues of relevance;

- Motivating them to engage well in the governance system;

- Securing the appropriate technical, skill and financial resources needed;

- Developing a clear mandate from their constituents and maintaining effective representational feedback and communication mechanisms; and

- Being involved in structured negotiation, including improving their negotiation capacity. 
Again, capacity development needs to occur in a way that is fair. Focusing on a few key stakeholders in a system at the expense of others will lead to unfair system outcomes.

\section{A Simple Framework for Governance Systems Analysis}

Through better defining the systemic context within which improved governance analysis occurs the following provides a framework for supporting more systemic analysis. Coined Governance Systems Analysis (GSA), this draws attention to the fact that analysis of any aspect of governance systems needs to be contextualized relative to the globe's broader governance context, and that governance can only be reasonably described in systemic/adaptive and not linear/rationalistic terms. In this regard, there are at least five ubiquitous steps that need to form the foundation of any application of the GSA process.

\subsection{Step 1: Contextualizing the System}

In taking a more systemic approach to governance analysis, a key foundation is scoping where the system being analyzed fits within the broader global system of governance themes, domains, sub-domains and scales (Haider and Rao2010). Using a wide literature, Emerson et al. (2012, p.8) refer to policy and legal frameworks, conflict history, network connections, culture and diversity as being important considerations in understanding governance context.

Placing the governance system under scrutiny within a wider context allows system analysts to avoid "fiddling while Rome burns", and flags whether or not the system is a relic left floundering while the bigger context has moved on. Such a contextualized approach also signals where transformational changes might be required in governance systems.

Simple articulation of the broad global framework of themes, domains and sub-domains of relevance to a particular governance system can contextualize the required analysis. Doing so can pre-emptively flag structural and functional issues of importance within system analysis. The example used in Table 1 illustrates how this could work in the context of governance analysis of the coastal management domain at various scales and within different sub-domains. Several international, national and provincial sub-domains, for example, can have big implications for coastal governance systems operating at the regional scale.

\subsection{Step 2: Understanding and Benchmarking Desired System Outcomes}

Once systemic context is understood, analysts can consider the outcomes the system is seeking to achieve and the structures and functions that need to be operating well. If the purpose of governance is to influence the flow of events to achieve public and private good, then it follows that governance analysis must relate to the outcomes being sought. Emerson et al. (2011) suggest that the parlous state of system outcomes (e.g.,climate change, global poverty, etc.) are often the key drivers behind the emergence of new or transformed governance systems. While they also consider leadership, human motivations and the need for collaboration to be drivers, this paper suggests these are part of the functional health of any governance system. A system exists, for example, whether there is strong leadership or not, but the systemic outcomes are likely be less healthy with poor leadership.

This step stresses that the state, condition and trend of the key outcomes of concern for 
governance need to be understood and agreed if GSA is to be valuable. Understanding outcome-oriented targets not only improves understanding of the system drivers, but guides analysis and enables benchmarking to measure the effect of governance reforms.

\subsection{Step 3: Describing the System's Structural and Functional Characteristics}

Step 3 presents the opportunity for analysts to understand the structural and functional aspects of the system and enables the scoping of the most fruitful lines on analytical inquiry. The typical key structural aspects of governance systems are outlined in Table 2 (from Dale \& Lane, 1993), while typical functional aspects are outlined in Table 3.

Table 2. Typical descriptors of key structural characteristics of governance systems

\begin{tabular}{|c|c|c|}
\hline $\begin{array}{l}\text { Descriptors for } \\
\text { Key Structural } \\
\text { Characteristics }\end{array}$ & Typical Descriptors & $\begin{array}{l}\text { Typical Structural } \\
\text { Outputs }\end{array}$ \\
\hline $\begin{array}{l}\text { Vision and } \\
\text { objective setting }\end{array}$ & $\begin{array}{l}\text { - Which institutions/ individuals are involved in } \\
\text { system vision and objective setting? } \\
\text { - Which other institutions and individuals in the } \\
\text { system need to be involved and what are their } \\
\text { visions and objectives for the system. } \\
\text { What are the policy and legal frameworks } \\
\text { underpinning vision and objective setting? }\end{array}$ & $\begin{array}{l}\text { - High level vision } \\
\text { and objective } \\
\text { statements that } \\
\text { set the scene for } \\
\text { strategy } \\
\text { development and } \\
\text { implementation }\end{array}$ \\
\hline $\begin{array}{l}\text { Analysis (research } \\
\text { and assessment) }\end{array}$ & $\begin{array}{l}\text { - Which institutions and individuals are involved in } \\
\text { research and assessment linked to the operation of } \\
\text { the system and what are their research and } \\
\text { assessment priorities? } \\
\text { - Which other institutions/ individuals need to be } \\
\text { involved in research and assessment? } \\
\text { - What are the policy and legal frameworks } \\
\text { underpinning analysis? }\end{array}$ & $\begin{array}{l}\text { - Strategic } \\
\text { research } \\
\text { programs. } \\
\text { - Strategic links } \\
\text { between research } \\
\text { programs and } \\
\text { system } \\
\text { monitoring. }\end{array}$ \\
\hline $\begin{array}{l}\text { Strategy } \\
\text { development }\end{array}$ & $\begin{array}{l}\text { - Which institutions/ individuals are involved in } \\
\text { strategy development and what are their strategic } \\
\text { priorities? } \\
\text { - Which other institutions/ individuals need to be } \\
\text { involved? } \\
\text { - What are the policy and legal frameworks } \\
\text { underpinning strategy development? } \\
\text { - What is the solutions mix developed to achieve high } \\
\text { level visions and objectives (i.e., the balance } \\
\text { between regulatory, suasive, market, education and } \\
\text { capacity building or collaborative approaches)? }\end{array}$ & $\begin{array}{l}\text { - High level } \\
\text { strategic plans } \\
\text { that drive } \\
\text { program } \\
\text { development and } \\
\text { implementation. } \\
\text { - A balanced mix } \\
\text { of strategic } \\
\text { solutions. }\end{array}$ \\
\hline Implementation & $\begin{array}{l}\text { Which institutions/ individuals are involved in a } \\
\text { strategic spread of implementation programs and } \\
\text { projects and what are their priorities? }\end{array}$ & $\begin{array}{l}\text { - Strategic } \\
\text { implementation } \\
\text { programs. }\end{array}$ \\
\hline
\end{tabular}




\begin{tabular}{|l|l|l|}
\hline & $\begin{array}{l}\text { - Which other institutions/ individuals should be } \\
\text { involved in implementation? } \\
\text { - What are the policy and legal frameworks } \\
\text { underpinning implementation? }\end{array}$ & $\begin{array}{l}\text { A mix of } \\
\text { regulatory, } \\
\text { voluntary, } \\
\text { suasive and } \\
\text { market-based } \\
\text { arrangements. }\end{array}$ \\
\hline $\begin{array}{l}\text { Monitoring, } \\
\text { evaluation and } \\
\text { review }\end{array}$ & $\begin{array}{l}\text { - Which institutions/ individuals are involved in } \\
\text { system monitoring, evaluation and review and what } \\
\text { are their related monitoring priorities for the system? } \\
\text { - Which other institutions/ individuals in the system } \\
\text { need to be involved in monitoring and evaluation? } \\
\text { - What are the policy and legal frameworks } \\
\text { underpinning monitoring, evaluation and review } \\
\text { within the system? }\end{array}$ & $\begin{array}{l}\text { Regularised state } \\
\text { of the system } \\
\text { monitoring and } \\
\text { reporting. } \\
\text { Strategic/ } \\
\text { periodic } \\
\text { evaluations of } \\
\text { key system parts. }\end{array}$ \\
\hline
\end{tabular}

Table 3. Typical descriptors of key functional characteristics of governance systems

\begin{tabular}{|c|c|}
\hline $\begin{array}{l}\text { Descriptors for Key Functional } \\
\text { Characteristics }\end{array}$ & Descriptors \\
\hline Knowledge Application: & $\begin{array}{l}\text { - Use of strategic analysis (research, assessment, } \\
\text { monitoring and evaluative work) across all structural } \\
\text { components of the system. } \\
\text { - Spread of knowledge across key system participants. } \\
\text { - Use of a spread of knowledge types, including social, } \\
\text { economic and environmental, traditional and historical } \\
\text { knowledge sets across the system. } \\
\text { - Use of technologies/soft systems to support knowledge } \\
\text { integration and decision support within the system. } \\
\text { - Existence of knowledge retention/management systems. } \\
\text { Existence and use of knowledge brokerage systems. }\end{array}$ \\
\hline Connectivity: & $\begin{array}{l}\text { - Existence of collaboration and negotiation within and } \\
\text { between key structural arrangements in the system. } \\
\text { - Relationships (including trust) within institutions involved } \\
\text { in different structural components of the system. } \\
\text { - Alignment of efforts and relationships across different } \\
\text { structural components within the system. } \\
\text { - Alignment between the governance system and other } \\
\text { relevant governance themes, domains and sub-domains. } \\
\text { - Alignment between spatial and time scales involved. }\end{array}$ \\
\hline Participant Decision Capacity: & $\begin{array}{l}\text { - Understanding of system issues of relevance amongst all } \\
\text { system participants (institutions and individuals). }\end{array}$ \\
\hline
\end{tabular}




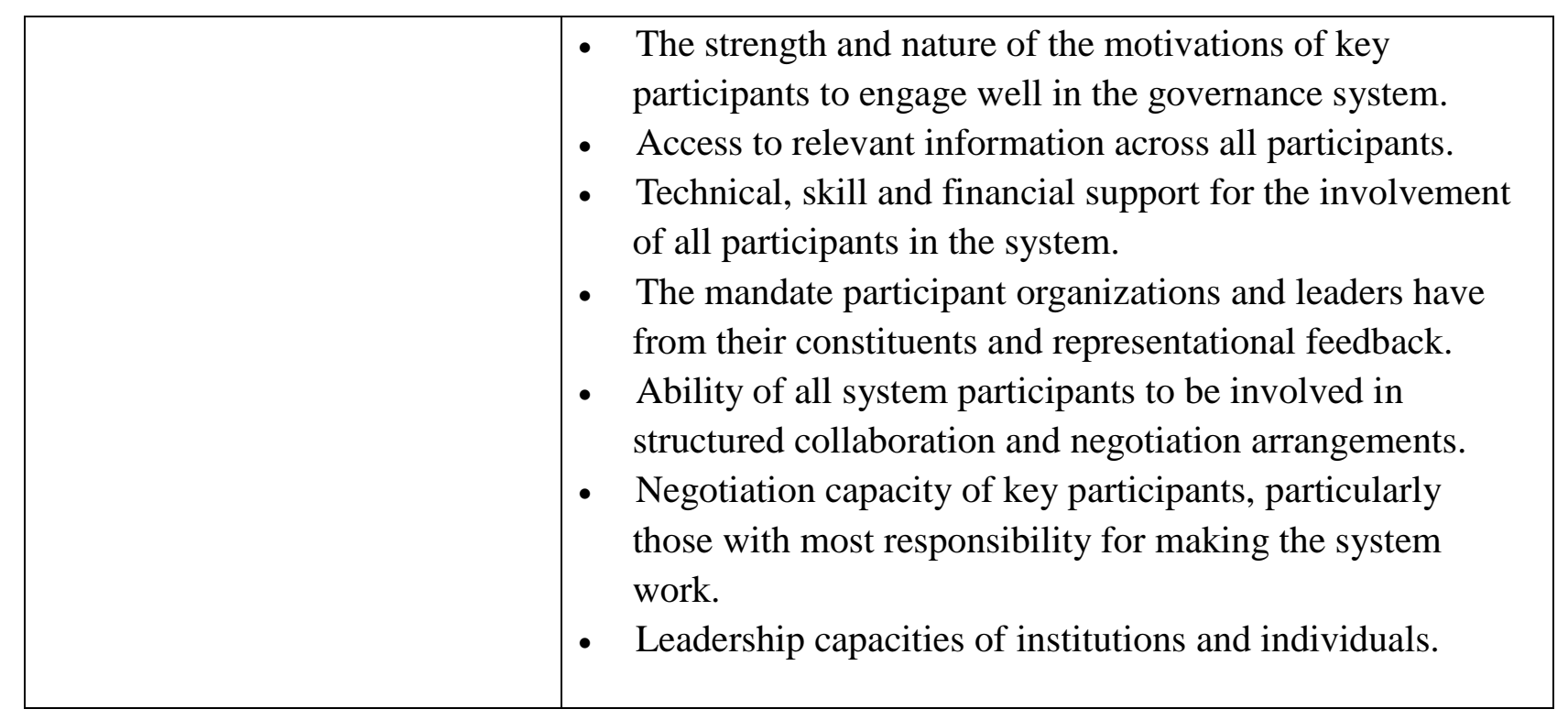

Analysing the structural and functional aspects of governance systems scopes the lines of analytical inquiry needed for describing the system. Step 3, then, should at least result in a clear matrix of the systemic lines of inquiry targeted to the meet the particular characteristics of the system and to help set the terms of reference for the system analysis. By way of example, having carefully drawn on the key structural and functional aspects of governance systems from Table 2 and Table 3, Table 4 provides an example "lines and inquiry matrix" that can be used to guide building a detailed understanding of the system.

Table 4.Sample GSA matrix with typical analytical points of inquiry.

\begin{tabular}{|c|c|c|c|}
\hline Function/ Structure & $\begin{array}{l}\text { Decision Making } \\
\text { Capacity }\end{array}$ & Connectivity & Knowledge Use \\
\hline $\begin{array}{l}\text { Visioning and } \\
\text { Objective Setting }\end{array}$ & $\begin{array}{l}\text { - Do capacities } \\
\text { exist to set higher } \\
\text { aspirational or } \\
\text { condition } \\
\text { targets? } \\
\text { - Do the relevant } \\
\text { stakeholders } \\
\text { have the } \\
\text { knowledge, } \\
\text { financial, human } \\
\text { and infrastructure } \\
\text { resources } \\
\text { required? } \\
\text { Do key } \\
\text { institutions } \\
\text { involved have } \\
\text { strong corporate } \\
\text { governance/ } \\
\text { continuous } \\
\text { improvement }\end{array}$ & $\begin{array}{l}\text { - Are relevant } \\
\text { stakeholders } \\
\text { actively connected } \\
\text { to } \\
\text { decision-making? } \\
\text { - Are visions and } \\
\text { objectives aligned } \\
\text { to higher and } \\
\text { lower scale visions } \\
\text { and objectives? } \\
\text { - Are collaborative } \\
\text { frameworks for } \\
\text { setting visions and } \\
\text { objectives well } \\
\text { designed? } \\
\text { Are there } \\
\text { frameworks for } \\
\text { bargaining and } \\
\text { negotiation over } \\
\text { setting visions and }\end{array}$ & $\begin{array}{l}\text { - Are all forms of } \\
\text { information } \\
\text { available for } \\
\text { vision and } \\
\text { objective setting? } \\
\text { - Are traditional } \\
\text { and historical } \\
\text { knowledge sets } \\
\text { being applied? } \\
\text { - Are appropriate } \\
\text { decision support } \\
\text { tools in place to } \\
\text { support scenario } \\
\text { analysis? }\end{array}$ \\
\hline
\end{tabular}




\begin{tabular}{|c|c|c|c|}
\hline & systems? & objectives? & \\
\hline $\begin{array}{l}\text { Research and } \\
\text { Assessment }\end{array}$ & $\begin{array}{l}\text { Are there strong } \\
\text { research and } \\
\text { analysis } \\
\text { capacities in } \\
\text { place to inform } \\
\text { other structural } \\
\text { components of } \\
\text { the system? } \\
\text { Are there strong } \\
\text { environmental, } \\
\text { economic and } \\
\text { social research } \\
\text { and analysis } \\
\text { capacities in the } \\
\text { system? }\end{array}$ & $\begin{array}{l}\text { Are there strong } \\
\text { collaborative } \\
\text { linkages between } \\
\text { research } \\
\text { institutions? } \\
\text { Are there effective } \\
\text { research brokerage } \\
\text { and } \\
\text { communication } \\
\text { arrangements } \\
\text { between research } \\
\text { provider and end } \\
\text { user stakeholders? } \\
\text { Are collaborative } \\
\text { arrangements in } \\
\text { place to integrate } \\
\text { social, economic } \\
\text { and physical } \\
\text { research? }\end{array}$ & $\begin{array}{l}\text { Are there systems } \\
\text { in place for long } \\
\text { term research } \\
\text { synthesis and } \\
\text { knowledge } \\
\text { retention? } \\
\text { There are broad } \\
\text { research priority } \\
\text { setting exercises } \\
\text { that need to be } \\
\text { refined? } \\
\text { Are all forms of } \\
\text { information } \\
\text { available for } \\
\text { system decision } \\
\text { making? }\end{array}$ \\
\hline $\begin{array}{l}\text { Strategy } \\
\text { Development }\end{array}$ & $\begin{array}{l}\text { Do capacities } \\
\text { exist in the } \\
\text { system to set } \\
\text { clear strategic } \\
\text { targets? } \\
\text { - Do relevant } \\
\text { stakeholders } \\
\text { have the } \\
\text { knowledge, } \\
\text { financial, human } \\
\text { and infrastructure } \\
\text { resources } \\
\text { available to make } \\
\text { the decisions } \\
\text { required? } \\
\text { Do the key } \\
\text { institutions } \\
\text { involved have } \\
\text { strong corporate } \\
\text { governance and } \\
\text { improvement } \\
\text { systems? }\end{array}$ & $\begin{array}{l}\text { Are all relevant } \\
\text { stakeholders } \\
\text { connected to } \\
\text { strategy } \\
\text { decision-making? } \\
\text { - Are strategies } \\
\text { aligned to visions } \\
\text { and objectives? } \\
\text { Are strategies } \\
\text { aligned to } \\
\text { higher/lower scale } \\
\text { strategy } \\
\text { development? } \\
\text { Are collaborative } \\
\text { frameworks for } \\
\text { setting strategies } \\
\text { well designed? } \\
\text { Do strategies } \\
\text { integrate an } \\
\text { appropriate } \\
\text { solutions mix? }\end{array}$ & $\begin{array}{l}\text { Is there social, } \\
\text { economic and } \\
\text { environmental } \\
\text { knowledge } \\
\text { relating to the } \\
\text { assessment of the } \\
\text { efficacy of key } \\
\text { strategies? } \\
\text { Are decision } \\
\text { support tools } \\
\text { available to } \\
\text { scenario test } \\
\text { alternative } \\
\text { strategies? }\end{array}$ \\
\hline Implementation & $\begin{array}{l}\text { Are there } \\
\text { capacities to } \\
\text { implement a } \\
\text { broad mix of } \\
\text { strategic } \\
\text { solutions? } \\
\text { Do the }\end{array}$ & $\begin{array}{l}\text { Are there effective } \\
\text { partnership and } \\
\text { integration } \\
\text { arrangements } \\
\text { between policy } \\
\text { and delivery } \\
\text { systems? }\end{array}$ & $\begin{array}{l}\text { - Are there research } \\
\text { efforts to inform } \\
\text { continuous } \\
\text { improvement in } \\
\text { implementation? } \\
\text { - Are local and } \\
\text { traditional }\end{array}$ \\
\hline
\end{tabular}




\begin{tabular}{|c|c|c|c|}
\hline & $\begin{array}{l}\text { implementation } \\
\text { players have the } \\
\text { financial, human } \\
\text { and infrastructure } \\
\text { resources to } \\
\text { implement? } \\
\text { - Do the key } \\
\text { institutions } \\
\text { involved have } \\
\text { strong corporate } \\
\text { governance and } \\
\text { improvement } \\
\text { systems? }\end{array}$ & $\begin{array}{l}\text { Do different } \\
\text { components of the } \\
\text { solution mix } \\
\text { collaborate? } \\
\text { - Are there effective } \\
\text { research brokerage } \\
\text { arrangements to } \\
\text { support } \\
\text { implementation? }\end{array}$ & $\begin{array}{l}\text { knowledge sets } \\
\text { informing } \\
\text { implementation? } \\
\text { - Are effective data } \\
\text { sets concerning } \\
\text { implementation } \\
\text { being managed } \\
\text { and retained? }\end{array}$ \\
\hline $\begin{array}{l}\text { Monitoring, } \\
\text { Evaluation and } \\
\text { Review }\end{array}$ & $\begin{array}{l}\text { Are there } \\
\text { effective } \\
\text { monitoring and } \\
\text { evaluation } \\
\text { capacities in the } \\
\text { system? } \\
\text { Are there } \\
\text { collective } \\
\text { monitoring } \\
\text { alliances in } \\
\text { place? } \\
\text { Are there defined } \\
\text { and independent } \\
\text { evaluation } \\
\text { capacities in the } \\
\text { system? } \\
\text { Are there } \\
\text { reporting } \\
\text { capacities to } \\
\text { enable high } \\
\text { levels of } \\
\text { accountability? }\end{array}$ & $\begin{array}{l}\text { Are there } \\
\text { integration } \\
\text { arrangements } \\
\text { between objective } \\
\text { setting and } \\
\text { monitoring } \\
\text { systems? } \\
\text { Are evaluative and } \\
\text { review } \\
\text { mechanisms } \\
\text { linked to long term } \\
\text { monitoring? } \\
\text { Are monitoring } \\
\text { and reporting } \\
\text { systems able to } \\
\text { influence strategic } \\
\text { processes and the } \\
\text { allocation of } \\
\text { resources? }\end{array}$ & $\begin{array}{l}\text { Are social, } \\
\text { economic and } \\
\text { environmental } \\
\text { outcomes from } \\
\text { the system being } \\
\text { monitored? } \\
\text { Are monitoring } \\
\text { and evaluation } \\
\text { data being } \\
\text { retained into the } \\
\text { long term? }\end{array}$ \\
\hline
\end{tabular}

Once clear lines of inquiry have been established, the main activity-based focus of Step 3 concerns describing the system in detail and presenting the results in a way that can help facilitate analysis in Step 4. This knowledge and data gathering approach needs to draw upon the widest possible range of sources. Applicable research techniques could include participant interviews, survey work, participant observation, detailed literature review, etc. Finally, depending on the resources available and the purpose of analysis, this step could result in detailed outputs through to simple tabular-based outputs.

\subsection{Step 4. Applying a Common set of Evaluative Principles}

Once thematic, domain and sub-domain scopes have been described across scales, and once clear lines of inquiry have been established using structural/ functional considerations, a simple matrix tool can be developed to facilitate either rapid appraisal or detailed analysis of 
governance systems. Doing so, however, requires use of a common and robust set of evaluative criteria. Based on Dale and Bellamy (1998) and via review of the governance literature (Graham et al., 2003, UNDP, 1997, OECD, 2004, Barrett, 2003), a common set of evaluation principles have been consolidated into seven core evaluative criteria.

The evaluative criteria outlined are designed to measure the health of structural/ functional components of the system. The best way to apply these principles is by the analyst considering the following key questions in respect to all lines of inquiry:

- Sustainability - Will governance activities be able to be sustained? Can system structures and functions be maintained in good health while the societal outcomes being pursued require them. Not all system parts should persist forever, but complex themes and domains can require enduring governance arrangements;

- Equity: Are governance activities fair for all stakeholders? Is there inherent fairness within system decision-making. People or institutions that don't see decision-making processes as fair are less likely to have lasting commitment to the outcomes;

- Accountability: Could those driving governance be held accountable by their constituents? Decision-makers need to be accountable to other participants and broader community interests. This is an important consideration for institutional leaders who are making decisions on behalf of a much broader constituency;

- Adequacy: Are governance activities sufficient to solve the problem? Adequacy checks if enough is being done to ensure governance activities are working;

- Effectiveness: Will governance actions solve problems effectively? Governance system activities need to result in meaningful outcomes (and not just outputs);

- Efficiency: Will governance actions solve problems efficiently? Efficiency can be measured numerically and qualitatively (e.g. costs) and can also provide an understanding of the relationship between inputs and outputs in governance;

- Adaptability: Can governance arrangements adapt with context? Governance systems need to be able to make strategic/tactical changes as changing circumstances present. Adaptability is critical in complex systems where knowledge is continually improving and where strategy implementation can lead to unexpected consequences.

With such a consistent set of evaluative criteria, the analysis of structural and functional elements of the system can become deeper and more robust. In doing so, analysts should draw evidence from the widest range of sources within the resources available. Adding to the descriptive work developed in Step 3, this at the very least could include more targeted interviews, participant observation, budgetary analysis, literature review, etc. All of this, however, needs to be well informed by a range of theoretical knowledge about specific aspects of system structure and function. Indeed, Steps 3 and 4 should be developed in an iterative fashion, as evidence unearthed in Step 3 could help refine Step 4 (and vice versa).

Holleyet al.,(2012) note that principles like those above are useful in evaluating any 
particular governance system. For demonstration purposes, through the application of these principles, Table 5 shows a sample application of GSA undertaken in a rapid appraisal exploring the health of governance systems in a particular sub-domain of coastal management within the Wet Tropics region of Queensland, Australia. This example also shows how GSA can help analysts consider potential governance reforms within systems (see Step 5).

\subsection{Step 5: Using GSA as a Basis for Reform}

Working through the GSA framework enables strategic reform of the targeted governance system. Reform is best achieved within a collaborative framework; hence the more system participants are involved in analytical design and the operation of Steps 1 through 5, the better. If GSA is used to inform adaptive management within governance systems, then benchmarking the health of the system and scheduling of regular review is also desirable (Taylor, et al., 2006). Through both expert consideration and participant discussion, however, Step 5 in GSA provides the foundation for the development of strategic reforms for system improvement. Again, the design of system improvements should always refer back to participant knowledge and the theory/practice literature; ensuring past mistakes are avoided.

As mentioned above, Table 5 shows an example of the sort of reform outputs possible from GSA. The example also collectively reinforces the importance of GSA being positioned within a broader governance systems context (Step 1), relating analysis to system outcomes (Step 2), explicitly considering structural and functional aspects of the system (Step 3), and keeping a weather eye across the several evaluative criteria outlined in Step 4.

\section{Applying Governance Systems Analysis in Practice}

GSA (applied in targeted, reform-oriented analysis of governance systems) is a practical framework applicable across or within any particular governance theme, domain or sub-domain. The approach can be adapted from use as a rapid appraisal technique, through to use as a comprehensive and adaptive analytical framework. It can equally be used as a dispassionate research tool, right through to being applied as an engaging practice-based reform tool. The application of GSA can also be easily adjusted to the budgetary and time constraints facing commissioning agencies.

GSA provides the basis for analysis of governance systems as a pre-cursor to developing, implementing and reviewing reform and commissioning agencies can consider the it application in a wide range of contexts. Government agencies may use it to develop and assessing critical reforms in government decision-making systems. Alternatively, disempowered communities or institutions can use the framework to develop and subsequently advocate their priorities for governance reform. Either way, the processes of fairer bargaining and negotiation within society, in the context of any theme, domain or scale, can only become stronger as a result of its considered application.

Some key factors in its application, however, are worthy of note:

- Best effect in participatory rather than expert assessment contexts. GSA is best applied in participatory decision-making, enabling all system participants to jointly analyse 
the health of their governance system and to negotiate and monitor more durable and trusted reforms in a structured way;

- Best applied within reform-oriented approaches. While GSA can be a tool for dispassionate analysis by experts, its greatest strength is in providing the evidence base required for more participatory approaches to governance reform;

- Creates a foundation for benchmarking and monitoring governance systems. GSA data outputs create the ideal foundation for establishing governance systems benchmarks and for monitoring progressive improvements in their health;

- Potential application in education and capacity building. When run in a participatory approach, or even within formal education and training courses, GSA provides a clear framework for education about governance and systemic improvement;

- Can determine risks and areas of strategic governance research. An useful outcome from GSA is that it can identify key areas of risk and strategic research that are required to help underpin future governance system improvements; and

- Someone needs to take leadership in and responsibility for facilitating continuous improvement in governance systems. To be healthy, all governance systems need someone in the system to take leadership in monitoring and driving continuous improvements. While government agencies are often best placed to lead and resource improvements in system health, leadership can come from any participant in the system. For best effect, the GSA process needs durable, dedicated resourcing and all system participants should have confidence in those leading/managing the analytical or reform agenda. Sadly, such systemic analyses are the exception rather than the rule.

As improved governance analysis is needed to achieve better outcomes from society's more intractable problems, it is hoped GSA provides a practical assessment framework. It is also hoped its wide application by analysts across environmental, social and economic themes, might also encourage greater interactions between currently disparate schools of governance analysis, all of which should be increasingly considered in a more global systemic context.

\section{Acknowledgement}

The research is financed by: Australian Government National Environment Research Program Tropical Ecosystems Hub.

\section{References}

Althaus, C., Bridgman, P., \& Davis, G. (2007). The Australian policy handbook (4th ed.). Sydney: Allen and Unwin.

Barrett, P. (2003). Better practice public sector governance. Canberra: ANAO.

Bouwen, R., \& Taillieu, T. (2004). Multi-party collaboration as social learning for interdependence: Developing relational knowing for sustainable natural resource 
management. Journal of Community \& Applied Social Psychology, 14(3), 137-153.

Bulkeley, H. (2005). Reconfiguring environmental governance: Towards a politics of scales and networks. Political Geography,24, 875-902.

Cundill, G., \& Fabricius, C. (2009). Monitoring in adaptive co-management: Toward a learning based approach. Journal of Environmental Management,90(11), 3205-3211.

Cash, D. W., Adger, W., Berkes, F., Garden, P., Lebel, L., Olsson, P. \&Young, O. (2006). Scale and cross-scale dynamics: Governance and information in a multilevel world. Ecology and Society, 11(2), 8.

Dale, A., \& Bellamy, J. (1998).Regional resource use planning: An Australian review. LWRRDC Occasional Paper - 9/98. Canberra: LWRRDC.

Dale, A. P., \& Lane, M. B. (1993). Strategic perspective analysis: A procedure for participatory and political social impact assessment. Society and Natural Resources,7(3): 253-267.

Dale, A., Taylor, N., \& Lane, M. (2002).Social assessment in natural resource management institutions. Melbourne: CSIRO Publishing.

Diamond. J. (2006). Collapse: How societies choose to fail or succeed. Camberwell, Vic: Penguin.

Dixon, J., \& Rhys, D. (2003). Analyzing global governance failure: A philosophical framework. Journal of Comparative Policy Analysis, 5, 209-226.

Dorcey, A. (1986). Bargaining in the governance of pacific coastal resources: Research and reform. University of British Colombia, Vancouver: Westwater Research Centre.

Emerson, K., Nabatchi, T., \& Balogh, S. (2011). An integrative framework for collaborative governance. Journal of Public Administration Research and Theory,2(2011).

Folke, C., Hahn, T.Olsson, P., \& Norberg, J. (2005). Adaptive governance for social-ecological systems. Annual Review of Environmental Resources, 30, 441-473.

Giovanni, A.\& Silver, B. (1999). Chaos and governance in the modern world system. Minnesota: Regents of the University of Minnesota.

Giddens, A. (1984). The constitution of society:Outline of the theory of structuration. Cambridge: Policy Press.

Graham, J., Amos, B.\& Plumptre, T. (2003). Principles of good governance in the $21^{\text {st }}$ century. Policy Brief No. 15. Ontario: Institute of Good Governance.

Haider, H., \& Rao, S. (2010). Political and social analysis for development policy and practice: An overview of five approaches. Birmingham: International Development Department, University of Birmingham.

Hajer, M. A.\& Wagenaar, H. (Eds.). (2003). Deliberative policy analysis: Understanding 
governance in the network society. Cambridge: Cambridge University Press.

Hoggarth, L., \& Comfort, H. (2010). A practical guide to outcome evaluation. Philadelphia: Kingsley Publishers.

Holley, C., Gunningham, N.\& Shearing, C. (2012). The new environmental governance. Milton Park: Earthscan.

Kemp, R., Parto, S.\& Gibson, R. B. (2005). Governance for sustainable development: Moving from theory to practice. Internatinal Journal of Sustainable Development, 8(1), 12-30.

Kenward, R., Whittingham, M., Arampatzisc, S. Manosd, B. D. Hahne, T. Terry, A. ... Rutz, C. (2011). Identifying governance strategies that effectively support ecosystem services, resource sustainability and biodiversity. National Academy of Sciences of the USA, 108(13), 5308-5312.

Leys, A. J., \& Vanclay, J. K. (2011). Social learning: A knowledge and capacity building approach for adaptive co-management of contested landscapes. Land Use Policy,28(3), 574-584.

Lockwood, M., Davidson, J., Curtis, A., Stratford, E., \& Griffith, R. (2010). Governance principles for natural resource management. Society and Natural Resources,23, 986-1001.

Macionis, J. J., \& Gerber, L. M. (2011).Sociology (7th ed.). Toronto, Canada: Pearson Inc.

Margerum, R. D. (1995). Integrated environmental management: Moving from theory to practice. Journal of Environmental Planning and Management,38(3), 371-392.

Morrison, T. H., McDonald, G. T., \& Lane, M. B. (2004). Integrating natural resource management for better environmental outcomes. Australian Geographer,35(3), 243-258.

Newig, J., \& Fritsch, O. (2009). Environmental governance: Participatory, multi-level - and effective? Environmental Policy and Governance, 19(3), 197-214.

OECD. (2004). OECD principles of corporate governance. Paris: OECD.

Ostrom, E. (2008). Polycentric systems as one approach for solving collective-action problems. Indiana: Indiana University Bloomington.

Paavola, J. Gouldson, A. \& Kluvánková-Oravská, T. (2009). Interplay of actors, scales, frameworks and regimes in the governance of biodiversity. Environmental Policy and Governance 19: 148-158.

Parker, C., \& Braithwaite, J. (2003). Regulation. In P. Cane \& M. Tushnet (Eds.), The Oxford handbook of legal studies. Oxford: Oxford University Press.

Plummer, R., \& Armitage, D. (2007). A resilience-based framework for evaluating co-management: Linking ecology, economics and society in a complex world. Ecological Economics, 61, 62-74. 


\section{Macrothink}

Journal of Public Administration and Governance ISSN 2161-7104 2013, Vol. 3, No. 3

Pullan, W., \& Bhadeshia, H. (2000).Structure in science and art. Cambridge: Cambridge University Press.

Rauschemayer, F., Berhofer, A., Omann, I., \& Zikos, D. (2009). Examining processes or/and outcomes: Evaluation concepts in European governance of natural resources. Environmental Policy and Governance, 19, 159-173.

Reed, M. G., \& Bruyneel, S. (2010). Rescaling environmental governance - rethinking the state: A three-dimensional review. Progress in Human Geography, 34(5), 646-653.

Stoker, G. (1998). Governance as theory: Five propositions. International Social Science Journal,50(155), 17-28.

Taylor B., McDonald. G., Heyenga, S. Hoverman, S., Smith, T., \& Robinson, C. (2006). Evaluation of regional planning arrangements for natural resource management 2005-06: Benchmark report II. Healthy Savanna Planning Systems Project, Tropical Savannas Management. Brisbane: CSIRO.

Thomas, J. W., \& Grindle, M. S. (1990). After the decision: Implementing policy reforms in developing countries. World Development,18(8), 1163-1181.

UNDP. (1997). Governance and sustainable human development. Geneva: UNDP.

Urry, J. (2000). Sociology beyond societies: Mobilities for the twenty-first century. London: Routledge.

Weiss, T. G. (2000). Governance, good governance and global governance: Conceptual and actual challenges. Third World Quarterly,21(5), 795-814.

Young, O. R., Berkhout, F., Gallopini, G. C., Janssen, M. A., Ostrom, E., \& van der Leeuw, S.. (2006). The globalization of socio-ecological systems: An agenda for scientific research. Global Environmental Change,16(3), 304-316. 
Table 5.An example output from application of GSA to an Australian coastal management sub-domainin the environmental theme.

\section{GSA Synthesis Sheet:}

Scale:

Theme:

Domain:

Sub-Domain:

Current System Outcomes:

Benchmark Timing:

Application Context:

Structure/ Function
Visioning and Object
Setting
Suggested Governance

Reform Priorities:

- Strong strategic planning

(objective and strategy setting)

alliance

established at regional scale between regional body, Councils and catchment groups.

- Preliminary 10 year strategic framework established.

- Structural reform to be negotiated within local catchment groups to ensure strong representative

Wet Tropics Region of Queensland, Australia

Environment

Australian Coastal Management

River Improvement Planning/Delivery

Poor river governance delivers sediment loads 4 times pre-European settlement into Great Barrier Reef. Annual cost of post-flooding disaster response rising exponentially. Degradation of cultural, recreational, aesthetic and biodiversity values in key river systems.

2012.

Researcher-led rapid appraisal for demonstration purposes.

\begin{tabular}{|c|c|c|}
\hline $\begin{array}{l}\text { Decision Making } \\
\text { Capacity }\end{array}$ & Connectivity & Knowledge Use \\
\hline $\begin{array}{l}\text { - No effective } \\
\text { regional capacities } \\
\text { to set clear river } \\
\text { improvement } \\
\text { visions/objectives. } \\
\text { - River } \\
\text { improvement } \\
\text { planning capacity } \\
\text { strong in } 1 \text { of } 5 \\
\text { Councils. } \\
\text { Six voluntary } \\
\text { catchment groups } \\
\text { with limited river } \\
\text { improvement } \\
\text { planning } \\
\text { capability. } \\
\text { Potential for high } \\
\text { level planning } \\
\text { capacity to be } \\
\text { established } \\
\text { between } \\
\text { councils/regional } \\
\text { body. } \\
\text { Relevant } \\
\text { stakeholders have } \\
\text { knowledge to }\end{array}$ & 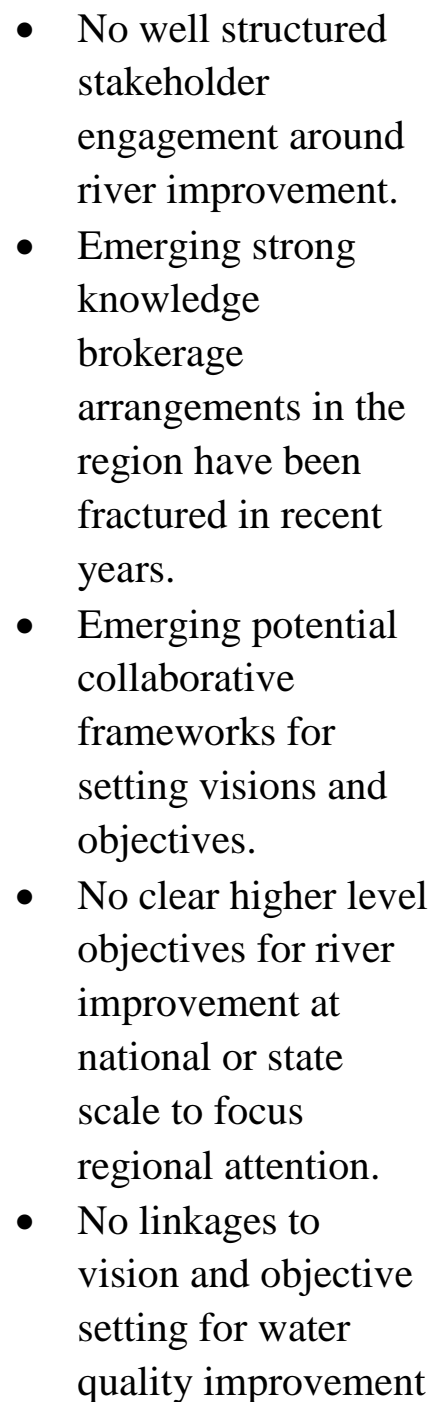 & $\begin{array}{l}\text { - Traditional/historica } \\
1 \text { knowledge of river } \\
\text { management } \\
\text { marginalized in } \\
\text { vision/objective } \\
\text { setting. } \\
\text { - No clear long term } \\
\text { river health research } \\
\text { arrangements to } \\
\text { inform } \\
\text { vision/objective } \\
\text { setting. } \\
\text { Reasonable } \\
\text { knowledge of river } \\
\text { flows/ aquatic } \\
\text { ecosystem health. } \\
\text { No clear river } \\
\text { management models } \\
\text { to inform objective } \\
\text { setting. }\end{array}$ \\
\hline
\end{tabular}




\begin{tabular}{|c|c|c|c|}
\hline $\begin{array}{l}\text { advisory } \\
\text { arrangements for } \\
\text { objective setting } \\
\text { and review. } \\
\text { - Immediate reform } \\
\text { required in State } \\
\text { level River } \\
\text { Improvement } \\
\text { Trust } \\
\text { legislative/funding } \\
\text { arrangements. }\end{array}$ & $\begin{array}{l}\text { inform decisions } \\
\text { for } \\
\text { vision/objective } \\
\text { setting, but limited } \\
\text { financial and } \\
\text { human resources. } \\
\text { - Key institutions } \\
\text { have variable } \\
\text { corporate } \\
\text { governance/ } \\
\text { continuous } \\
\text { improvement. }\end{array}$ & $\begin{array}{l}\text { or water allocation } \\
\text { in region. }\end{array}$ & \\
\hline $\begin{array}{l}\text { Research and Analysis } \\
\text { Suggested Governance } \\
\text { Reform Priorities: } \\
\text { - Specific major } \\
\text { River } \\
\text { Improvement } \\
\text { Program to be } \\
\text { integrated into } \\
\text { next round } \\
\text { Australian } \\
\text { Government } \\
\text { funding program } \\
\text { by } 2014 . \\
\text { Informal research } \\
\text { capacities } \\
\text { identified and } \\
\text { linked to emerging } \\
\text { regional river } \\
\text { improvement } \\
\text { alliance. }\end{array}$ & 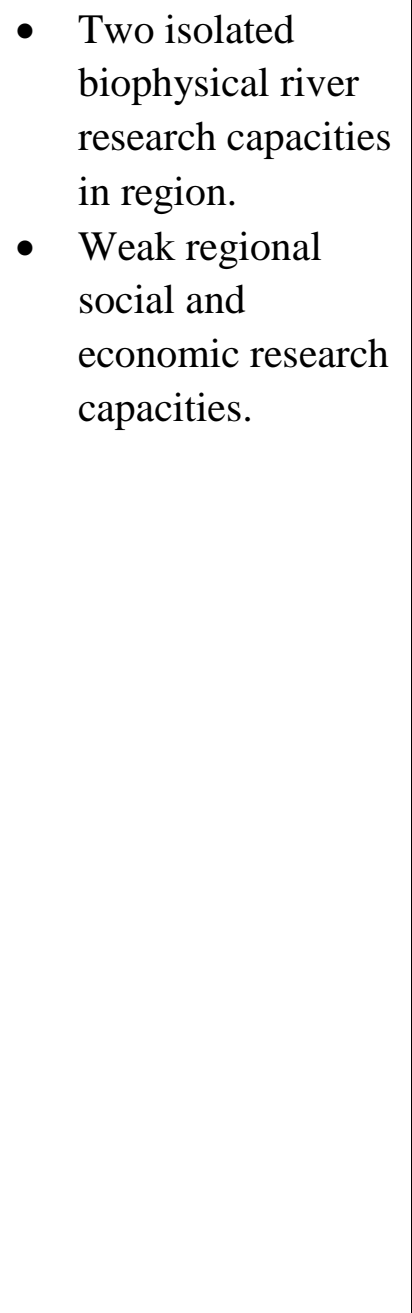 & $\begin{array}{l}\text { No regional } \\
\text { collaborative } \\
\text { research frameworks } \\
\text { to link research to } \\
\text { planning and } \\
\text { management for } \\
\text { progressive river } \\
\text { improvement. } \\
\text { - Poor integration } \\
\text { between available } \\
\text { biophysical, social } \\
\text { and economic } \\
\text { research. }\end{array}$ & 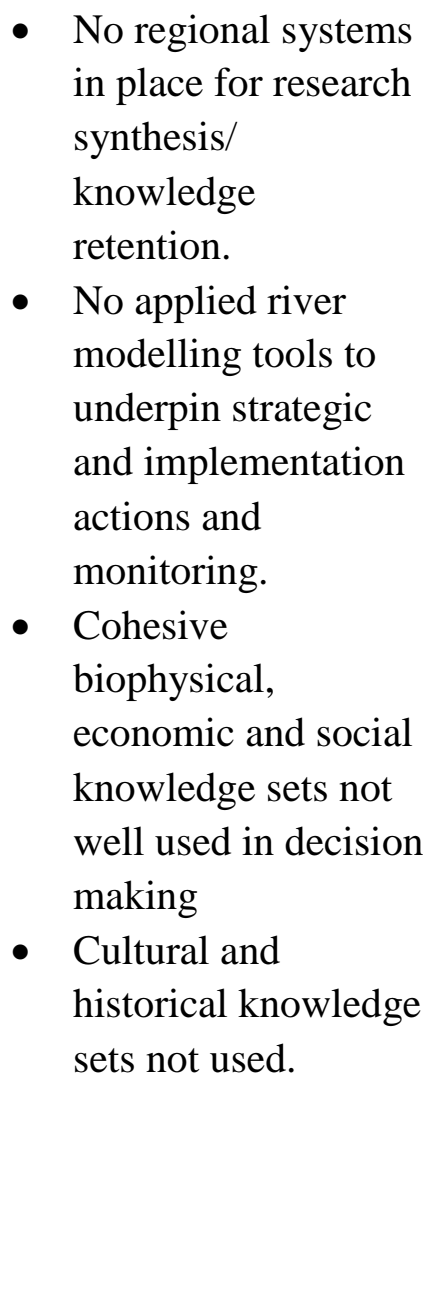 \\
\hline $\begin{array}{l}\text { Strategy Development } \\
\text { Suggested Governance } \\
\text { Reform Priorities: } \\
\text { - Strong objective } \\
\text { setting/ strategic }\end{array}$ & $\begin{array}{l}\text { With exception of } \\
\text { water quality, no } \\
\text { current regional } \\
\text { capacities to set } \\
\text { strategic regional } \\
\text { river improvement }\end{array}$ & $\begin{array}{l}\text { Regional } \\
\text { stakeholders not } \\
\text { facilitated to } \\
\text { negotiate regional } \\
\text { strategy } \\
\text { development. }\end{array}$ & $\begin{array}{l}\text { Poor social, } \\
\text { economic and } \\
\text { environmental } \\
\text { knowledge for } \\
\text { strategy } \\
\text { development? }\end{array}$ \\
\hline
\end{tabular}




\begin{tabular}{|c|c|c|c|}
\hline $\begin{array}{l}\text { planning alliance } \\
\text { established } \\
\text { regionally } \\
\text { between regional } \\
\text { body, Councils } \\
\text { and catchment } \\
\text { groups. } \\
\text { Preliminary } 10 \\
\text { year strategic } \\
\text { framework to be } \\
\text { established. } \\
\text { Structural reform } \\
\text { to be negotiated } \\
\text { within local } \\
\text { catchment groups } \\
\text { to ensure } \\
\text { representative } \\
\text { advisory } \\
\text { arrangements for } \\
\text { objective setting/ } \\
\text { strategy } \\
\text { development and } \\
\text { review. } \\
\text { Higher level } \\
\text { policy in } \\
\text { investment reform } \\
\text { required under } \\
\text { River } \\
\text { Improvement } \\
\text { Trust Act and } \\
\text { Natural Disaster } \\
\text { Relief } \\
\text { Arrangements. }\end{array}$ & $\begin{array}{l}\text { targets and } \\
\text { strategy } \\
\text { development. } \\
\text { - Could regionalise } \\
\text { financial capacity } \\
\text { of Councils, } \\
\text { landholders/catch } \\
\text { ment groups to } \\
\text { invest in river } \\
\text { improvement. } \\
\text { Existing } \\
\text { regulatory } \\
\text { capacities under } \\
\text { River } \\
\text { Improvement Act } \\
\text { weak and rarely } \\
\text { used. } \\
\text { No market-based } \\
\text { river improvement } \\
\text { capacities. } \\
\text { Limited suasive } \\
\text { strategy } \\
\text { development } \\
\text { capacities. }\end{array}$ & $\begin{array}{l}\text { Weak State level } \\
\text { river improvement } \\
\text { strategies not } \\
\text { actively mobilising } \\
\text { strategic regional } \\
\text { action } \\
\text { - Local government } \\
\text { river improvement } \\
\text { works increasingly } \\
\text { strategic. } \\
\text { Poor integration } \\
\text { between market, } \\
\text { regulatory and } \\
\text { suasive strategies. } \\
\text { Little integration } \\
\text { between floodplain } \\
\text { management, } \\
\text { disaster relief, land } \\
\text { use planning and } \\
\text { river improvement } \\
\text { strategies. }\end{array}$ & 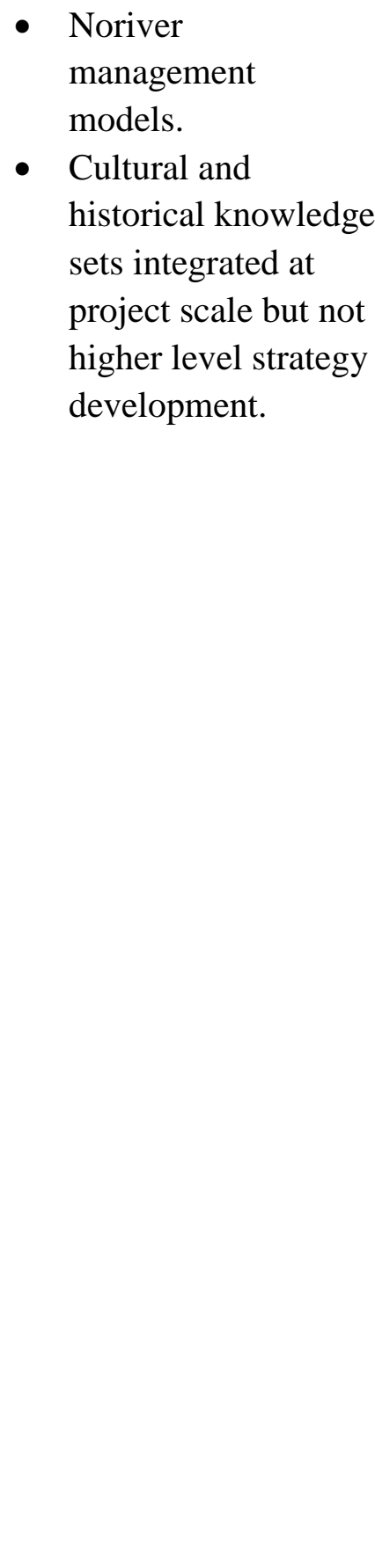 \\
\hline $\begin{array}{l}\text { Implementation } \\
\text { Suggested Governance } \\
\text { Reform Priorities: } \\
\text { - Structural reform } \\
\text { in Councils to } \\
\text { re-craft and } \\
\text { integrate river } \\
\text { improvement, } \\
\text { revegetation and }\end{array}$ & $\begin{array}{l}\text { Real capacities } \\
\text { exist within } \\
\text { Councils to carry } \\
\text { out structured } \\
\text { river improvement } \\
\text { works. } \\
\text { - Capacity in } \\
\text { regional body to } \\
\text { manage } \\
\text { market-based and }\end{array}$ & $\begin{array}{l}\text { Emerging } \\
\text { partnership and } \\
\text { integration } \\
\text { arrangements } \\
\text { between policy and } \\
\text { delivery systems. } \\
\text { - No effective } \\
\text { research brokerage } \\
\text { arrangements for } \\
\text { implementation. }\end{array}$ & $\begin{array}{l}\text { - } \\
\text { research sufficient } \\
\text { continuous } \\
\text { improvement in } \\
\text { implementation. } \\
\text { - Local and traditional } \\
\text { knowledge informs } \\
\text { implementation } \\
\text { projects in an ad hoc } \\
\text { fashion. }\end{array}$ \\
\hline
\end{tabular}




\begin{tabular}{|c|c|c|c|}
\hline $\begin{array}{l}\text { pest management } \\
\text { delivery. } \\
\text { Regional body to } \\
\text { develop effective } \\
\text { market-based and } \\
\text { suasive delivery } \\
\text { systems in } \\
\text { partnership with } \\
\text { Council. } \\
\text { Medium term } \\
\text { significant } \\
\text { refinancing deal to } \\
\text { be struck between } \\
\text { State, } \\
\text { Commonwealthan } \\
\text { d Councils. }\end{array}$ & $\begin{array}{l}\text { suasive } \\
\text { implementation } \\
\text { mechanisms. } \\
\text { Councils and } \\
\text { NRM sector do } \\
\text { not have the } \\
\text { required financial } \\
\text { capacity for } \\
\text { effective } \\
\text { implementation. } \\
\text { Strong corporate } \\
\text { governance in } \\
\text { regional body and } \\
\text { Councils, though } \\
\text { corporate and } \\
\text { structural reform } \\
\text { required in River } \\
\text { Improvement } \\
\text { Trusts. }\end{array}$ & $\begin{array}{l}\text { - Improving } \\
\text { integration between } \\
\text { Council-based } \\
\text { vegetation, pest and } \\
\text { parks management } \\
\text { and river } \\
\text { improvement and } \\
\text { engineering } \\
\text { capabilities }\end{array}$ & $\begin{array}{l}\text { - Data sets concerning } \\
\text { implementation not } \\
\text { being } \\
\text { managed/retained. }\end{array}$ \\
\hline $\begin{array}{l}\text { Monitoring, Evaluation } \\
\text { and Review } \\
\text { Suggested Governance } \\
\text { Reform Priorities: } \\
\text { - Councils begin } \\
\text { regular } \\
\text { coordinated } \\
\text { monitoring/reporti } \\
\text { ng of annual } \\
\text { property/infrastruc } \\
\text { ture damages. } \\
\text { Local CSIRO/ } \\
\text { University } \\
\text { alliance to identify } \\
\text { and develop } \\
\text { highest priority } \\
\text { monitoring } \\
\text { systems for } \\
\text { sediment, } \\
\text { biodiversity and } \\
\text { cultural losses. }\end{array}$ & $\begin{array}{l}\text { - Limited cohesive } \\
\text { monitoring and } \\
\text { evaluation } \\
\text { capacities in } \\
\text { region for river } \\
\text { improvement. } \\
\text { - No existing } \\
\text { collective } \\
\text { alliances across } \\
\text { the system in } \\
\text { place for effective } \\
\text { monitoring. } \\
\text { Independent } \\
\text { evaluation } \\
\text { capacities exist in } \\
\text { the region in } \\
\text { consultancy, } \\
\text { Council/regional } \\
\text { body. } \\
\text { No formal } \\
\text { reporting } \\
\text { capacities to } \\
\text { enable high levels } \\
\text { of accountability }\end{array}$ & $\begin{array}{l}\text { Emerging potential } \\
\text { partnership for } \\
\text { integrated } \\
\text { monitoring systems } \\
\text { via Council, regional } \\
\text { body, catchment } \\
\text { groups and research } \\
\text { sector. } \\
\text { - Evaluative and } \\
\text { review mechanisms } \\
\text { not linked to long } \\
\text { term monitoring. } \\
\text { Monitoring/reportin } \\
\text { g systems do not } \\
\text { influence } \\
\text { strategy/resource } \\
\text { allocation, though } \\
\text { effort to use damage } \\
\text { estimates to } \\
\text { encourage } \\
\text { investment. }\end{array}$ & $\begin{array}{l}\text { - Social, economic } \\
\text { and environmental } \\
\text { outcomes are not } \\
\text { being monitored. } \\
\text { - Limited monitoring } \\
\text { and evaluation data } \\
\text { available/being } \\
\text { retained into the } \\
\text { long term. }\end{array}$ \\
\hline
\end{tabular}




\section{Macrothink}

\section{Copyright Disclaimer}

Copyright reserved by the author(s).

This article is an open-access article distributed under the terms and conditions of the Creative Commons Attribution license (http://creativecommons.org/licenses/by/3.0/). 